\title{
Religious Education and Containment of Radical Elements: The Case Of Pondok Schools in Malaysia
}

\author{
Fauziah Fathil, ${ }^{\mathrm{a}, *}$ Wiwin Oktasari, ${ }^{\mathrm{b}}$
}

${ }^{a}$ Kulliyyah of Islamic Revealed Knowledge and Human Sciences, International Islamic University Malaysia. ${ }^{b}$ Kulliyyah of Islamic Revealed Knowledge and Human Sciences, International Islamic University Malaysia. *Corresponding author: fauziahfathil@iium.edu.my

\begin{abstract}
Article history
Received: 10/10/2016

Received in revised form:13/1/2017

Accepted: 04/03/2017

Abstract

Islam and militant activities are indeed two ill-assorted and incompatible elements. While the former enjoins harmony and peace, the latter is essentially destructive in nature with no regard for either lives or properties The occurrence of many events which involved radical or militant elements today caused a growing concern that education too, might have been used by some irresponsible groups to spread their radical ideas in order to recruit followers or supporters where young minds are taught to hate people of other beliefs or ideologies and to commit destructive acts. In Malaysia, while phenomenon involving radical ideas is generally under control, still there have been some allegations that a certain style of education particularly of pondok system, being involved in militantrelated activities. Based on qualitative approach or content-analysis, this paper attempts to seek out reasons for such allegations, highlighting certain issues and prior events that happened in the country which might have contributed to these contentions. The paper also provides possible means and ways, in view of the existing scenario in Malaysia, in making sure that religious education in the country remains free from the unwanted radical elements or ideas.
\end{abstract}

Keywords: Religious, Education, Radical and Malaysia. 


\subsection{INTRODUCTION}

Looking at the world today, one could see how Islam, especially in non-Muslim countries, has been branded as a faith that preaches hatred or hostile feelings towards non-believers and that Muslims as people of radical or militant ideology whose desire is to strike terror in the hearts of non-Muslims through the use of force. Such are the prevailing views among non-Muslims towards Islam and Muslims today. While there is no truth to these prejudiced perceptions, it is not difficult to see why the non-Muslims view Islam and its followers insuch a manner. The ongoing and ever increasing militant activities and events involving Muslim individuals and groups served as an impetus for such contentions though Islam itself does not condone militant ideas nor are majority Muslims worldwide in support of radical views and use of force against believers of other creeds. In fact, the radical groups are non-discriminatory in their actions that Muslims too are subject to torturous and cruel ways as can be witnessed in events that are taking place in the Middle East today. In Malaysia, while the activities of radical groups in the country are under control, there have been allegations that some endeavors to spread radical ideas have taken place, one through traditional religious education system known as pondok schools. This paper, hence, aims to examine the claim in view of the socio-political context of Malaysia while at the same time highlight the contributory causes and factors for the alleged phenomenon as well measures undertaken by the Malaysian authority in dealing with the problem. Finally, some precautionary and preventive steps are suggested to ensure that radical ideas would not seep into the religious education system of the country.

\subsection{METHODOLOGY}

In conducting this research, the researchers opted for qualitative or content-analysis approach. Given the contemporary nature of the topic under study, the researchers made use of primary sources such as newspaper articles as well as e-documents which highlight the present pondokrelated and militant-related developments in Malaysia. Furthermore, other sources employed are those of secondary in nature and they include journals and books or works written on the issues concerned.

In going through the materials, there were a number of steps involved namely, data collection, categorisation of data, data analysis and finally, witing up or presentation of research findings. Since the phenomenon of radical or militant activities in general sense, is still very much present particularly in the surrounding Southeast Asian region, though in the case of Malaysia itself the situation is essentially under control, the researches have also outlined some recommendations and suggestions in order to provide hindsights to those agencies or parties that are related to the religious education system or pondok schools in the country on how to prevent possible spread of militant ideas particularly among citizens of the pondok schools, and eventually to avoid the occurence of militant acitivites involving either pondok students or teaching staff.

\subsection{HISTORICAL BACKGROUND: DEVELOPMENT OF RELIGIOUS EDUCATION IN MALAYSIA}

The beginning of religious education in Malaysia began long before the coming of colonial powers. Starting from informal learning sessions held at mosques, surau, rulers'courts and homes of religious individuals, this practice of seeking religious knowledge evolved into a more structured system known as pondok schools. Similar to what is called pesantren in Indonesia, the pondok which originated from the Arabic word al-funduq (hut) refers to small huts of students built around the home of tok guru (grand teacher) who imparts religious or Quranic knowledge to his disciples following a devised syllabus with the assistance of several other teachers. In Malaysia, this education system can be traced back to the $19^{\text {th }}$ century, though in one state i.e. Kelantan there are views that it has begun ever since $14^{\text {th }}$ or $16^{\text {th }}$ century given the state's proximity to Patani in southern Siam where the system is believed to have first started. On the other hand, instead of Patani, some believe that the pondok system practiced in the Malay states 
actually originated from Sumatera, Indonesia (Haji Mydin, 2014; Hashim and Langgulung, 2008; Mohd Noor, 2012).

By the late $19^{\text {th }}$ century, more pondok were built throughout the country generating both material and moral support from local Malay-Muslim communities as well as Malay leaders and rulers. Despite the introduction of modern or Western-style education by British in the early $20^{\text {th }}$ century, the pondok continued to flourish since not only was the former, in the view of MalayMuslim parents, devoid of religious or spiritual content but also, particularly in the case of English schools run by Christian missionaries, could lead to their children being converted to Christian faith.

Following the rise of Islah and Tajdid or Islamic reform movement in the early $20^{\text {th }}$ century, the religious education system in Malaysia underwent a major change where a new type of school was built known as madrasah to suit the more challenging contemporary world in facing Western imperialism. Instead of mainly focusing on religious studies, the madrasah also taught modern subjects such as science and mathematics, apart from having a more conducive teaching and learning environment for both staff and students in terms of equipments and facilities. Propagated mainly by religious scholars who were influenced by reformist ideas known as Kaum Muda (Young Faction), the system attracted many that some pondok were transformed into madrasah (Noor, 2008). Nevertheless, despite the growing popularity of the new madrasah, the pondok system favored particularly by conservative scholars known as Kaum Tua (Old Faction) continued to survive especially in the northern and eastern states of Malaysia, namely Kedah, Kelantan and Terengganu.

Throughout the post-war years, the religious education began to assume a new role that it became a catalyst for anti-colonial struggle where religious scholars associated with the pondok and madrasah were among those who fought for independence of the country. Such potential role of the institutions in relation to politics persisted throughout the post-independent years into the $21^{\text {st }}$ century, and it is this particular aspect of the institutions namely, their affiliation with politics, that radical elements somehow tend to be associated with the religious education in Malaysia, particularly in the $20^{\text {th }}$ and $21^{\text {st }}$ centuries. Apart from the traditional pondok and reform-inspired madrasah, it is important to mention here that there have been other institutions of religious education that appeared in the subsequent years namely, Sekolah Agama Rakyat (People's Religious School) and Sekolah Menengah Kebangsaan Agama (National Secondary Religious School). Some of them are actually originated from the existing pondok and madrasah and their emergence followed increasing demand among the Malay-Muslim community especially from the 1970s onwards for a proper education that combined modern and religious subjects, and one that is in line with the national education system. Equipped with better facilities and more comprehensive curriculum, these schools are either fully or partly funded by the federal government and state governments, which in turn caused the institutions subject to a greater supervision and monitoring by the Ministry of Education of the federal government as well as relevant bodies of state governments.

\subsection{RADICAL GROUPS AND THEIR ACTIVITIES IN MALAYSIA}

In the post-9/11 setting, we have witnessed the widespread use of exchangeable words namely, Islamic radicalism, Islamic fundamentalism, and Islamic extremism which all refer to a kind of "radical piety" of some irresponsible Muslim individuals or groups who are prone to commit terrorist and militant actions (Singh, 2007). As a country, Malaysia too is not free from radical activities or events involving some self-claimed Muslim individuals and groups. Here, some militant groups and incidents in which they involved are worthy of mention.

While there have been some groups preaching deviationist Islamic teachings in the country, the real threat to the people and country which involved radical elements did not appear until early $21^{\text {st }}$ century. As in some countries, these threats notably increased in the wake of the event of September 11, 2001 that stern measures have to be taken by the government of Malaysia to eliminate them. The first to arise was a militant group known as Al-Ma 'unah, abbreviated from Persaudaraan Ilmu dalam Al-Ma`unah (Brotherhood of Al-Ma`unah Inner Power). Based in 
Malaysia, it aimed to establish an "Islamic state" and overthrow the Malaysian government in 2000. Having involved in several minor explosions at few places on the outskirts of Kuala Lumpur, the group was finally suppressed by Malaysian Army and Royal Malaysian Police Forces after a brief combat fighting in July 2000 (Noor, 2007). The members of the group were detained and the leader of the group along with two others, were sentenced to death by hanging.

Shortly after, a group known as Kumpulan Mujahidin Malaysia (Mujahidin Group of Malaysia) appeared, challenging the Malaysia authorities as they wanted to end Mahathir's government and create a regional Islamic state comprising southern Thailand, Malaysia, Indonesia, southern Philippines. Having linked up to some overseas militant groups such as Jemaah Islamiah and Gerakan Mujahidin Islam Patani, the members of the groups were believed to have undergone military training in Afghanistan or Pakistan to topple down the government by force (Noor, 2007). To remove the threat, tens of members of the group were detained by the Malaysian authorities under ISA (Internal Security Act) in 2000, 2001 and 2002 (Utusan, 12 Aug, 2001). More than 200 cases of suspected Muslim militants associated with the group were investigated by the Malaysian police throughout year 2012 alone.

Another group worthy of mention, though its activities mainly centered in Indonesia and Philippines is Jemaah Islamiah or JI (Islamic Brotherhood). Being linked to international militant group al-Qaeda, JI is a radical group based in Southeast Asia that aims to establish an Islamic state in the region covering Malaysia and Indonesia among others. Having involved in 2002 Bali bombing and other similar incidents in Indonesia and Philippines, the groups is also believed to have connection with some other groups such as Moro Islamic Liberation Front and Abu Sayyaf Group in Philippines. Though the impact of its operations on Malaysia is minimal, its recruits are from among people of this country apart from that of Indonesia, Singapore and Philippines.

Following the recent outbreak of conflicts in Iraq and Syria which saw the rise of a militant groups known as Islamic State (IS), Islamic State for Iraq and Syria (ISIS) or Daish, Malaysia as with some other countries in the world today also experienced a new wave of threat posed by its own people who have been influenced by the militant ideology of IS. So far, a few hundred individuals have been arrested and detained by the authorities for being suspects of terrorist attacks in Kuala Lumpur, making police stations and military camps as their targets, also involving in attempts to kidnap some individuals of high profile. Some of the suspects are believed to have had military training in Afghanistan and Indonesia and some to have connection with the IS. It is a worrying scenario as it was found that not only the IS sympathizers comprise ordinary masses or laymen such as technicians, teachers, factory workers, etc, but also several low-ranking military personnel as confirmed by Royal Malaysian Police Force. What is more, not only did these individuals who have been influenced by the radical ideology of the IS involve in unwanted incidents in the country, but some sought to directly participate in the conflict that is going on in the Middle East, fighting alongside the IS or some other groups in Iraq and Syria.

Despite the government's attempt to prevent individuals from getting involved in the conflict, that is by detaining those suspected of trying to enter Iraq or Syria, yet, tens have been identified to have gone overseas to join the IS or other smaller militant groups, and of this number, some have died while fighting against the army of Syrian President Bashar al-Asad. Among those killed some were identified to be former members of KMM while some were former detainees of ISA (Utusan, 22 Aug, 2014). By July 2015, it is reported that the number of Malaysian citizens who have been arrested by the police for being sympathizers of IS or attempting to go to Iraq and Syria since 2013 has reached 110 (Zolkepli, 2015), and this number would not likely subside until and unless the conflict in the Middle East comes to an end or more efficient preventive or counter-measures are taken by the Malaysian authorities.

\subsection{RELIGIOUS EDUCATION AND RADICAL IDEAS IN 21ST CENTURY MALAYSIA}

As radical groups sometimes used or manipulated Islam to justify their actions, it is not surprising that religious education too in certain cases was linked up to radical or militant ideology. Such a claim is particularly notable among Western media which often times generalized whatever that 
is related to Islam and Muslims without looking at the real issues at hand or the context in which particular events or incidents involving Muslims took place.

In Malaysia, the association between religious education and radical elements are two-fold; one is related to domestic politics of the country which involves contention between the ruling Malay party of UMNO (United Malay National Organization), which leads the government coalition, and its political opponent, PAS (Pan-Malaysian Islamic Party); and second, that is related to worldwide terrorism of contemporary period. Pertaining to internal politics, the struggle for power between the UMNO and PAS explained the restricting measures imposed by the government in the 1990s and early 2000 particularly onto pondok schools, madrasah and Sekolah Agama Rakyat that were under the PAS's influence. This was in response to increasing popularity of PAS in some states especially among the citizens of the pondok schools with whom PAS have established close connection since 1950s and 1960s, which naturally led to a conviction among some UMNO leaders that the pondok served as centers for preaching hatred against the government or "centers of obscurantist teaching and militant anti-government activity" (Noor, 2008).

Nevertheless, generally the sentiment projected by the pro-PAS's pondok and madrasah towards the government was more of a hostile feeling and devoid of 'radical' elements in the strictest sense of the word or being 'radical' to the extent of using physical force. It is more about PAS and not UMNO being the favorite party which the people vote for during elections. One exception, however, was the case of Madrasah Islahiyyah Diniyyah, a madrasah in the state of Kedah that was under the influence of PAS, where it was linked to radical elements based on its stance and reactions towards the ruling government. In one particular event of 1985 known as the "Memali Incident", the founder of the madrasah, Ustaz Ibrahim Mahmood nicknamed Ibrahim Libya along with some of his supporters were killed in a clash with the government authorities as they resisted his arrest by the police. Prior to the incident, Ibrahim Libya had been very vocal against the government led by UMNO, calling for jihad or open revolt to end the ruling government (Noor, 2008).

Following the event of September 11, 2001 and the spread of terrorist activities worldwide in the recent years, religious education has been affiliated even more so with radical elements. In Malaysia, it is the traditional pondok to a greater extent, and the madrasah to a lesser extent, that have been singled out as potential centers propagating radical ideas in favor of terrorism and recruiting Muslim militants. Yet, it is important to highlight here that unlike some other Muslim countries such as Pakistan and Indonesia, whose a certain number of their traditional religious schools have somewhat been identified to have connection with radical ideology and militant groups (Horgan, 2012), the prevailing scenario in Malaysia is that such a phenomenon is more invalid than real. So far, observations made with reference to particularly the pondok in Malaysia and its relation with radical ideology and militant groups such as al-Qaeda, JI or Daish are merely unfounded allegations or claims. This has repeatedly been emphasized by the government authorities and relevant agencies in numerous occasions maintaining that the pondok schools in the country are free from radical elements or terrorist activities and that there are no established links between the pondok and international militant groups.

It is estimated that at present there are about 250 to 300 pondok schools throughout the country with heavy concentration in the state of Kedah, Kelantan and Terengganu, and lesser number in Negeri Sembilan, Pahang, Perak, Johor, Malacca, Selangor, Federal Territory of Kuala Lumpur and Penang. It is also estimated that the current total number of pondok school students is around 15,000 while teachers around 900-1,000. Lack of comprehensive studies made so far on the contemporary pondok schools contributed to the absence of exact figures and information in relation to the institution, plus the independent nature of the pondok itself where many of these schools preferred to be free of government control and outside interference made it difficult for interested parties to collect accurate information about the institution. For the second factor too, consequently, only one third of the total pondok in Malaysia is reported to have been registered with religious departments of respective states (Rozlin, 2014). What is more, some of the present pondok schools decided not to use the word 'pondok' for their institutions, rather some other 
names which in turn led people to perceive them to be something that they are not. Among different names used include Madrasah, Sekolah Agama Rakyat, Kulliyyah, Pusat Pengajian Pondok, Pusat Pendidikan Islam, Sekolah Menengah, Maahad Tahfiz, Pertubuhan Murid-Murid, Madrasah Tahfiz, Yayasan and Pondok Moden. Of these names, the word "madrasah" is the most commonly used interchangeably with the word "pondok", hence, caused some people to confuse the so-called madrasah for traditional pondok and vice-versa.

Still, the occurrence of numerous terrorist attacks by the so-called Muslim groups worldwide have affected and tarnished the image of pondok schools in the country in that as traditional schools, the pondok are being accused particularly by Western media as breeding grounds for Islamic militants who render support to militant groups such as the IS. While such an allegation, as insisted by the government authorities, lacked substance, still, there have been some incidents which, in the view of the West, served as proofs for their claim. The first of such events was the closing down by the Malaysian government in 2002 of a madrasah at Ulu Tiram in the state of Johor known as Madrasah Lukmanul Hakim. Founded by Abu Bakar Bas'asyir, an Indonesian cleric who lived in exile in Malaysia, the madrasah was suspected as having connection with regional militant group, the JI (Noor, 2008). A more recent event that also attracted the attention of the Western media was the participation of Mohd Lotfi Ariffin, former Head of Information of PAS Youth of Kedah state in the conflict in the Middle East where he fought the Syrian army and died in September 2014. Not only did his link with the Islamic party PAS seems to contribute the wide coverage by the media, but more importantly, because of his connection with traditional pondok where he was the founder of one pondok school known as Madrasah Nurul Hidayah in the state of Kedah. A video was in fact made by newspaper The New York Times in 2014 entitled "The Jihadist in Our Family" in which family members of Mohd Lotfi were interviewed regarding his involvement in Syria and ended with what seemed to be remarks by a brother of Mohd Lotfi, who is also a co-founder and teacher of the pondok, encouraging its students to follow the footsteps of his younger brother waging jihad war in Syria (The Malaysian Times, March 5, 2015).

Mohd Lotfi apparently was not the only person who wished to involve in the conflict in Syria. By 2015, about 100 self-proclaimed jihad fighters from Malaysia have been reported to have landed in Syria to fight the army of Syrian President, Bashar Asad. Some of them maintained that they are not affiliated with any groups including the IS, rather they were there as independent jihadists fighting against the tyranny of Syrian army who killed innocent Muslim men, women and children. Of this number, it was alleged that at least two were related to a pondok school in Kedah and one to a pondok school in Kelantan.

No doubt, these isolated cases involving self-proclaimed jihad fighters and pondok served as basis of arguments for the Western media to justify that the pondok institutions in Malaysia do involve in teaching radical or militant ideology to its students. In actual fact, however, they are no more than isolated cases and the charges made are far from the truth. This was confirmed by Malaysian federal government as well as state governments such as that of Kedah, Kelantan and Terengganu where most of traditional pondok are located, after close scrutiny and investigations (The Sun Daily, 25 Aug, 2015; The Malaysian Times, March 5, 2015). The same observation was made by the Malaysian Police Force after some investigations and inquiries (Bernama, 5 March, 2015). Even the brother of Mohd Lotfi, the fighter who died in Syria, when approached by local newspapers confirmed that he did not encourage his pondok students to do jihad in that country as portrayed in The New York Times' video, nor did his pondok and its 180 students ever involve in militant activities or teachings (The Malaysian Times, March 5, 2015). Apart from the relevant authorities, the allegations were also rebuked by pondok teachers and individuals since the institution, they argued, aims to produce disciplined and good-mannered individuals who view tok guru as their role models in terms of behaviors and attitudes. This is in line with Islam since the religion Islam preaches against violence. Moreover, they maintained the pondok also exposes students to deep knowledge of Islam, something that is lacking among those who joined militant groups including the IS, and that the syllabus used at pondok was generally devised by tok guru and religious figures of the institution meant to recruit individuals to adhere to true Islamic principles and be responsible for the country, religion and society (Mubassyir, 2016) 
Looking back at the incidents linking up the pondok schools to radical elements, one can discern that the one that was related to internal politics such as the "Memali Incident" was more the outcome of political struggle between the ruling government and opposition party and that such a case was exceptional in the sense that throughout the history of Malaysian politics, there had hardly been direct physical clashes between supporters of PAS of pondok institutions and the government authority. On the contrary, the second scenario which involved self-proclaimed jihadists of pondok background who fought in the Middle East is very often due to the individuals' lack of deep or true knowledge about Islam and the concept of jihad. Having been attracted to the notion or promise of having their sins cleansed away if they joined the jihad war, the individuals left the country to fight alongside the IS army. In addition, they were some who have been influenced by messages and call for Jihad posted on social media run by militant groups who continuously strived to attract Muslim individuals worldwide to join their cause or campaign of terror in the name of religion of Islam.

\subsection{COUNTER-MEASURES TO CONTAIN MILITANT ACTIVITIES}

The Malaysian government, having realized the possible threat that militant activities or groups could pose through the traditional pondok system have taken several measures to ensure that such a possibility could be avoided. In the wake of 9/11 incident and also several events involving militant activities that happened in the country, coupled with the prevailing situation which saw Malaysian citizens going out to involve in some war campaigns particularly in the Middle East, the Malaysian government has established Yayasan Pembangunan Pondok Malaysia (YYPM) or Malaysian Pondok Development Foundation on August 1, 2012. Masterminded by Prime Minister Najib Razak, the foundation was registered as a non-governmental association with the Prime Minister himself as its patron (Portal of Yayasan Pembangunan Pondok Malaysia, 2016)

The aim of YYPM is to give recognition to the pondok institution and pondok citizens for their contribution in the development of Islamic education in the country and for producing many religious figures throughout the years. It is also meant to recognize the contributions of religious scholars, tok guru and pondok supervisors in producing students who are equipped with religious and Quranic studies, and to eliminate the idea of pondok graduates as second class students, Muslim fanatics and fundamentalists. In order to ensure the survival of the pondok system and make it competitive and relevant to modern age, the YYPM strives to improve and develop the pondok institution, learning structure and activities with the help of NGOs, government agencies and private sectors (Portal of Yayasan Pembangunan Pondok Malaysia, 2016). This is in view of the fact that some pondok either due to financial problems or their reluctance to reach out to outside help as they wished to remain free from external control, are inadequate in terms of facilities and up to date learning and teaching methods. For the said purpose also, in 2015 budget, the government allocated 25 million Malaysian ringgit to education of registered pondok (Rozlin, 2014). In another occasion, in 2012, the government allocated 740 thousands Malaysian ringgit for the development of 19 pondok and tahfiz schools in the state of Kedah. Through the government efforts too, in improving the status of pondok by introducing changes in the learning system, graduates of some pondok schools could now pursue their tertiary education at local universities in the country (The Star, 10 Nov, 2013). About 240 pondok have so far been recorded by the YYPM and established links with it.

Apart from the YYPM, there are also other NGOs supported by state governments which play the monitoring role over pondok schools in Malaysia. One such association is Pusat Pembangunan Pondok Berhad (PPPB) or Centre of Development of Pondok Corporation registered under Malaysian Company Act on April 22, 1995. Recognized by State Government of Kelantan, the members of PPPB include pondok teachers, tok guru or founders of pondok and individuals who are committed to improve and develop the pondok system. A similar association can be found is northern state of Kedah called Persatuan Jemaah Pondok-pondok Kedah or Kedah Pondok School Association which monitored pondok institutions in the state in collaboration with Kedah Islamic Religious Department. In Terengganu, a NGO called Adat Melayu Terengganu (MAIDAM) or Terengganu Malay Customs is working hand in hand with the Religious Department of that state to do the monitoring work. 
In addition, monitoring of pondok is also being done by some government bodies at both national and state level. At national level there are Home Ministry led by Deputy Prime Minister, Prime Minister's Department and Jabatan Kemajuan Islam Malaysia (JAKIM) or Malaysian Islamic Development Department which oversee the running of the pondok in the country. Meanwhile at the state level, Majlis Agama Islam or Islamic Religious Department with which pondok schools are supposed to register, are made responsible to monitor and check on the operation of the pondok schools in their respective states.

For serious cases which involve security of national interests, the government has passed some laws to curb militant activities. Among them include Akta Kesalahan Keselamatan (Langkah-Langkah Khas) (SOSMA) or Security Offences (Special Measures) Act of 2012 which replaced detention preventive ISA (Internal Security Act) of 1960. There are also Akta Pencegahan Jenayah (Pindaaan and Pemerluasan) (POCA) or Crime Prevention Act (Amendment and Expansion) of 2013 and Rang Undang-Undang Pencegahan Keganasan (POTA) or Prevention of Terrorism Act of 2015 which allow the Malaysian authority to detain suspects of acts of terrorism without trials in order to prevent possible threats. A special unit called Counter Terrorism Department has been set up by the Malaysian Police Force to investigate cases related to terrorism. Given the widespread networking of some international and regional militant groups, the Malaysian Ministry of Defense has established and maintained good cooperation with other countries' intelligence agencies worldwide.

\subsection{RECOMMENDATIONS AND SUGGESTIONS}

In view of the ongoing threat emanated from radical or militant ideology of some international and regional groups, it is imperative that all parties and not just the government authorities, do regular monitoring on the religious education in the country in order to make sure that the system and everything that is related to it whether the students, teachers, syllabus, etc. is not in any way under the influence of radical or militant ideas. For that purpose, it requires the involvement of various parties such as government agencies and leaders, societal leaders, parents and teachers of pondok students, local community surrounding the pondok schools, local Muslim scholars, nongovernmental associations, private sectors as well as media.

Apart from the enforcement of the terrorism-preventive laws, a closer cooperation need to be fostered between the government and pondok institution especially those under the influence of PAS or those which have for so long insisted on being independent without any collaboration with government agencies. Yet, it requires a right approach on the part of the government so as to avoid being seen as merely trying to manipulate the pondok for political interests, i.e. to get the pondok citizens to support or vote for the government against the opposition. Stricter scrutiny on social media by the government could also help to prevent the spread of radical ideas among the masses. On the part of societal leaders, parents and local community, awareness about the threat of radical elements which caused young Malaysians to leave the country and involve in some militant activities needs to be heightened. This would ensure that everybody would play his or her role to contain this problem.

Meanwhile, the teachers and founders of pondok undoubtedly, play a very important role since they are part of the system, hence, their alertness and attentiveness is crucial in making sure that the radical ideas would not penetrate into their institutions or influence their students. A closer cooperation with different agencies such as Religious Department, JAKIM, etc. could help them to get the needed information on how to detect or prevent the unwanted problem. Moreover, clear explanations on the concept of jihad as outlined by the holy Quran need to be emphasized from time to time to overrule some misleading interpretations of jihad as understood by some Muslim individuals and groups. This is the responsibility of the teachers and founders of pondok schools who themselves are religious scholars with in-depth knowledge of Islam, and local Muslim scholars or functionaries including mufti, imam, dakwah missionaries, etc.

As for non-governmental associations and private sectors, they could also assist by forming a close relationship with the pondok either through community services, social networking and the like. Through this way, they could indirectly impart awareness to the pondok citizens or 
community about the danger of radical ideas, and means and ways to prevent them from being influenced by views or acts of terrorism. Finally, the media, being at the forefront of the modern age of globalization with boundless information at its disposal needs to convey and spread the right message alerting all parties of their responsibilities to check on terrorism and at the same time ensuring that only true and genuine information available to readers and masses to avoid unnecessary anxieties or fears.

\subsection{CONCLUSION}

It is imperative that religious education either in Malaysia or other Muslim countries for that matter, is free from radical elements or activities, be it in favor of certain political groups or of ideology of some militant groups, especially when Islam itself, which is the basis of religious education, promotes peace and condemns obstructive acts which could lead to loss of properties and innocent lives. Notwithstanding this fact, still, given the situation of the world today where easy access to information is the norm, radical ideas or militant ideologies could easily spread and influence Muslim masses. In the case of Malaysia, though there have been cases of radical or militant activities which involved its citizens of pondok background, the situation is generally still under control. Yet, it does not mean that preventive measures are not necessary or could be relaxed. Since the security of the country and nation is at stake, all parties must get involved in making sure that the religious education in the country remains free from undesirable radical or militant elements.

\section{References}

A. Noor, Farish, et al. (eds.). (2008). The madrasa in Asia: Political activism and transnational linkages. Amsterdam Univ. Press: Amsterdam.

Abuza, Zachary. (2003). Militant Islam in Southeast Asia, crucible of terror. Colorado: Lynne Rienner Publishers.

Askandar, Kamarulzaman. (2005). Understanding and managing militant movements in Southeast Asia. Penang: SEACSN Publication.

Bukan tempat lahir militant. Harian Metro. (2016, 22 January). Retrieved from http://www.hmetro.com.my/node/109227. Access date: 11/9/2016.

Don't be prejudiced against 'pondok'schools - Mufti Kelantan. Astro Awani. (2016, 12 July). Retrieved from http://english.astroawani.com/malaysia-news/dont-be-prejudiced-againstpondok-schools-kelantan-mufti-110836. Access date: 11/9/2016.

Dua ahli Muhajahidin ditahan ISA 2 tahun. Utusan Online. (2001, 2 August). Retrieved from http://ww1.utusan.com.my/utusan/info.asp? $=2001 \& \mathrm{dt}=0812 \& \mathrm{pub}=$ Utusan_Malaysia\&sec $=$ Muka_Hadapan\&pg=mh_03.htm. Access date: 11/9/2016.

Ganguly, Sumit, et al. (eds.). (2010). The Routledge handbook of Asian security studies. Oxon and New York: Routledge.

Haji Mydin, Haji Mohd Mahadi and Ahmad, Noor Sufiza. (2014). "The system of Islamic studies at madrasah (sekolah pondok)." Journal of Mechanical Manufacturing (J-Mfac). 1.

Hashim, Che Noraini and Langgulung, Hassan. (2008). "Islamic religious curriculum in Muslim countries: The experiences in Indonesia and Malaysia." Bulletin of Education \& Research. 30 (1), 1-19.

Horgan, John and Braddock, Kurt (eds.). (2012). Terrorism studies: A Reader. London and New York: Routledge.

Kamal, Ayu Musa. (2015, 22 January). Kedah government ropes in pondok school association to curb militant activities. Bernama. Retrieved from http://www.themalaysianreserve.com/new/story/kedah-government-ropes-pondok-schoolassociation-curb-militant-activities. Accessed date: 11/9/2016. 
Kedah kerjasama dengan Persatuan Jemaah Pondok bendung aktiviti militant. Astro Awani. (2015, 23 January). Retrieved from http://www.astroawani.com/berita-malaysia/kedah-kerjasamadengan-persatuan-jemaah-pondok-bendung-aktiviti-militan-52639. Accessed date: 11/9/2016.

Madrasah and pondok religious achools in Kedah not involved in militant activities - Kedah police chief. Bernama. (2015, 5 March). Retrieved from http://www.bernama.com/bernama/v8/ge/newsgeneral.php?id=1114273. Accessed date: $11 / 9 / 2016$.

Madrasah, pondok religious schools in Kedah not involved in militant activities - Police. The Malaysian Times. (2015, 5 March). Retrieved from http://www.themalaysiantimes.com.my/madrasah-pondok-religious-schools-in-kedah-notinvolved-in-militant-activities-police/. Accessed date: 11/9/2016.

Mohamed, Zabidi. (2003). Rahsia dalam rahsia Maunah, kebenaran yang sebenar. Kuala Lumpur: Zabidi Publication.

Mohd Nor, Mohd Roslan. et al. Islamic Educational System in Kelantan, Malaysia: Traditional and Modern Approaches. Middle-East Journal of Scientific Research. 11 (9): 1238-1243. 2012. IDOSI Publications.

Mubassyir, Muhammad Ammar. (2016, 28 January). Kami tak lahirkan pengganas. Sinar Online. Retrieved from http://www.sinarharian.com.my/edisi/utara/kami-tak-lahirkan-pengganas1.478673. Accessed date: 11/9/2016.

New pride for sekolah pondok. The Star Online. (2013, 10 November). Retrieved from http://www.thestar.com.my/news/education/2013/11/10/new-pride-for-sekolah-pondok/. Accessed date: 11/9/2016.

Noor, Elina. (2007). Al-Ma'unah and KMM in Malaysia in Andrew T.H. Tan (ed.). A handbook of terrorism and insurgency in Southeast Asia. UK: Edward Elgar Publishing Limited,167-193.

Offical Portal of Pusat Pembangunan Pondok Berhad. Retrieved from https://epondok.wordpress.com/. Accessed date: 11/9/2016.

Official Portal of Yayasan Pembangunan Pondok Malaysia. http://yppm.org.my/. 11/9/2016.

Pondok militant: Dewan ulama PAS sangkal Mashitah. Harakah Daily. (2014, 4 July). Retrieved from http://arkib.harakahdaily.net/arkibharakah/index.php/arkib/berita/lama/2014/7/61181/pondokmilitan-dewan-ulama-pas-sangkal-mashitah.html. Accessed date: 11/9/2016.

Pondok schools slowly get attention. The Malaysian Times. (2013, 8 November). Retrieved from http://themalaysiantimes.com.my/pondok-schools-slowly-get-attention/. Accessed date: $11 / 9 / 2016$.

Rozlin, Izwan, Husin, Hasniza, et al. (2014, 3 November). Sekolah pondok jauh ketinggalan. Sinar Online. Retrieved from http://www.sinarharian.com.my/nasional/sekolah-pondok-jauhketinggalan-1.329887. Accessed date: 11/9/2016.

Singh, Bilveer. (2007). The Talibanization of Southeast Asia, losing the war on terror to Islamist Extremists. London: Praeger Security International.

Singh, Daljit. (2009). Terrorism in South and Southeast Asia in the coming decade. Singapore: ISEAS Singapore and Macmillan Publishers.

Thomas, R. Murray. (2006). Religion in schools: controversies around the world. Connecticut and London: Praeger.

Tiga rakyat Malaysia yang ditembak di Syria, bekas Kumpulan Mujahidin Malaysia (KMM). Utusan Online. (2014, 22 August). Retrieved from http://www.utusan.com.my/utusan/Jenayah/20140822/je_02/Pernah-ditahan-ISA-rompakbank\#ixzz3B6Zp4rCt

Zolkepli, Farik. (2015, 10 July). Cops stop militants' terror plan, investigation leads to arrest. The Star Online. Retrieved from http://www.thestar.com.my/news/nation/2015/07/10/cops-stopmilitants-terror-plans/. Accessed date: 11/9/2016. 
Fauziah Fathil and Wiwin Oktasari / UMRAN - International Journal of Islamic and Civilizational Studies. Vol.4, no. 1 -1, pp. 60 - 70

172 pondok schools not involved in extremism or militancy. The Sun Daily. (2015, 25 August). Retrieved from http://www.thesundaily.my/news/1531082. Accessed date: 11/9/2016.

64 pondok pengajian Islam di Terengganu bebas IS. BH Online. (2016, 11 July). Retrieved from http://www.bharian.com.my/node/172753. Accessed date: 11/9/2016. 